Volume 9

\title{
Extreme Sports and Extreme Liability: The Effect of Waivers of Liability in Extreme Sports
}

Amanda Greer

Follow this and additional works at: https://via.library.depaul.edu/jslcp

\section{Recommended Citation}

Amanda Greer, Extreme Sports and Extreme Liability: The Effect of Waivers of Liability in Extreme Sports, 9 DePaul J. Sports L. \& Contemp. Probs. (2012)

Available at: https://via.library.depaul.edu/jslcp/vol9/iss1/4

This Article is brought to you for free and open access by the College of Law at Digital Commons@DePaul. It has been accepted for inclusion in DePaul Journal of Sports Law by an authorized editor of Digital Commons@DePaul. For more information, please contact digitalservices@depaul.edu. 


\title{
EXTREME SPORTS AND EXTREME LIABILITY: THE EFFECT OF WAIVERS OF LIABILITY IN EXTREME SPORTS
}

\author{
Amanda Greer
}

\section{INTRODUCTION}

Imagine that a skier in a base jumping competition is about ready to jump off a cliff. Once the skier jumps off the cliff, usually the bindings of the skis will come off and the parachute will open, enabling a safe landing. However, in this situation, the bindings of the skis come off, but the parachute fails to open. The skier subsequently crashes to the ground, sustaining extremely serious injuries that leave the skier paralyzed. As a result of the injuries, the skier files an action against the sponsors $^{1}$ involved in putting on the competition, claiming that they were negligent in giving him a defective parachute. The sponsors assert that the skier signed a liability waiver barring all claims, even negligence.

The scenario above is one that presents several problems. For example, does signing a waiver of liability bar a claim of negligence against the sponsor of a sporting event? Does a skier involved in base jumping assume the risk of a parachute not opening? Does the sponsor have a duty to not increase those risks already inherent in the nature of the sport of base jumping? These are just a few questions that would be asked to see determine whether the skier could recover for the sustained injuries.

The sport of snowboarding, like the example of base jumping above, is known as an extreme sport. ${ }^{2}$ A sport is defined as an activity that is done for enjoyment or thrill, which requires physical exertion, elements of skill, and involves a potential risk of injury. ${ }^{3}$ An extreme sport, on the other hand, is classified as being physically hazardous, featuring a combination of speed, height, danger, spectacular stunts,

\footnotetext{
1. Merriam-Webster Dictionary Online, http:/www.merriamwebster.com/dictionary/sponsor? show $=0 \& \mathrm{t}=1320940281$ (last visited Nov. 10, 2011). A sponsor is defined as a person or organization that pays for or plans and carries out a project or activity. The term "sponsor" will be used throughout this paper to refer to organizations and promoters of a sporting event.

2. Matt Williamson, The History of Extreme Sports (2007), http://www.catalogs.com/info/ sports/history-of-extreme-sports.html.

3. Truong v. Nguyen, 156 Cal. App. 4th 865, 880 (Cal. Ct. App. 2007).
} 
and varying weather conditions. ${ }^{4}$ Athletes who participate in extreme sports exceed traditional safety limitations to create new disciplines in the sport. ${ }^{5}$ For example, individuals who engage in extreme skiing make dangerous runs down mountains over uncharted terrain. ${ }^{6}$ The enhanced danger posed by cliffs, crevasses, and extremely steep slopes is what elevates traditional snow skiing to an extreme level. ${ }^{7}$ Some popular sports that have become extreme sports as a result of their extreme elements are extreme skiing, snowboarding, mountain biking, inline skating, and white-water kayaking. ${ }^{8}$ Other extreme sports include wakeboarding, street luge, skateboarding, and freestyle biking events. ${ }^{9}$ Snowboarding, skateboarding, and freestyle biking are performed on ramps, inclines, or in a half-pipe, some with walls as high as fifty feet. ${ }^{10}$

The fear that drives many people away from the risks of extreme sports may be the same ingredient that keeps others coming back for more. ${ }^{11}$ By feeling a lack of danger in everyday activities, people may feel compelled to seek out danger or risk. ${ }^{12}$ Thus, during the last decade, participation in extreme sports has soared. ${ }^{13}$ While participation in team sports declined by a quarter in the last decade, the number of teenagers who skateboard, snowboard, or inline skate increased more than five times. ${ }^{14}$ Many of these extreme sports were made popular by the $\mathrm{X}$ Games, which has become known as the Olympics of extreme sports competitions on ESPN. ${ }^{15}$ The $X$ Games are comprised of the Winter X Games, which are held in January or February, and

4. World English Dictionary, http://dictionary.reference.com/browse/extreme+sport (last visited Sept. 19, 2011).

5. Williamson, supra note 2.

6. Id.

7. $I$ d.

8. Id.

9. Free Online Encyclopedia, http:/encyclopedia2.thefreedictionary.com/extreme+sports (last visited Sept. 19, 2011).

10. $I d$.

11. Brian Handwerk, National Geographic New, Fear Factor: Success and Risk in Extreme Sports, (July 9, 2004), http://news.nationalgeographic.com/news/2004/07/0709_040709_science risk.html.

12. Williamson, supra note 2.

13. David Hornton, Extreme Sports and Assumption of Risk: A Blueprint, 38 U.S.F. L. Rev. 599, 602 (2004). Such sports include skydiving, bungee jumping, rock climbing, hang-gliding, motocross, BMX, snowboarding, wake-boarding, kite-boarding, and skateboarding.

14. $I d$. at 603 .

15. Kate Pickert, A Brief History of the $X$ Games (Jan. 22, 2009), http:/www.time.com/time/ nation/article/0,8599,1873166,00.html. 
the Summer X Games, which are usually held in August. ${ }^{16}$ The Winter X Games is the leading winter action sports competition and is compiled of the greatest winter action sport athletes from around the world. ${ }^{17}$ Winter sports in the X Games include skiing, snowboarding, snowmobiling, snow skating, and ice climbing. ${ }^{18}$ Summer sports in the X Games include freestyle BMX, motocross, skateboarding, surfing, bungee jumping, water sports, inline skating, street luge, sky surfing, and sport climbing. ${ }^{19}$ The $\mathrm{X}$ Games have become so popular that about fifteen big-name sponsors have bought advertising packages reportedly worth between $\$ 1.5$ million and $\$ 3$ million. ${ }^{20}$ It has also been reported that the $\mathrm{X}$ Games will expand to six action sports competitions annually: two in the United States and four internationally, beginning in 2013. ${ }^{21}$ The 1998 and 2002 Olympics also began to feature extreme snowboarding events in a half-pipe, in which snowboarders performed jumps, rotations, and mid-air maneuvers. 22

Extreme Sports, by their nature, are inherently dangerous. ${ }^{23}$ The risk of injury is extremely high. ${ }^{24}$ This poses a problem for sponsors of an event because they will want to protect themselves from a lawsuit that may arise from an athlete's injury. In many liability waivers, athletes assume all risks involved in the sport, even the sponsors own negligence. The purpose of this article is to explain why it is against public policy for sponsors of an event to be allowed to contract away their own negligence in extreme sports. Athletes already assume the risks inherent in the sport, but they should not be expected to assume a risk above those inherent in the sport and suffer an injury that has been the result of a sponsor's negligence. A sponsor, on the other hand, should not be responsible for an athlete's injury that results from a risk inherent in the sport. Therefore, this article proposes a modification of liability waivers to remove the term "negligence" and include a form of comparative fault, where the athlete and the sponsor

16. Webster's Online Dictionary, http://www.websters-online-dictionary.org/definitions/X+ GAMES?cx=partner-pub-0939450753529744\%3Av0qd01-tdlq\& cof=FORID\%3A9\&ie=UTF-8 $\& q X+$ GAMES\&sa $=$ Search $\# 906$ (last visited Nov. 8, 2011).

17. Id.

18. Id.

19. Id.

20. Mike Bresnahan, $X$ Games Become Extremely Popular The Sun Sentinel, (Aug. 13, 2003), available at $\mathrm{http} / / /$ articles.sun-sentinel.com/2003-08-13/news/0308130139_1_x-games-sk ateboarders-nba-finals.

21. Matt Higgins, $X$ Games to Expand to Six International Events in 2013 ESPN, (May 13, 2011), http://xgames.espn.go.com/article/6553598/x-games-expand-six-international-events-beginning-2013.

22. Free Online Encyclopedia, supra note 9.

23. Williamson, supra note 2.

24. World English Dictionary, supra note 4. 
will share different percentages of fault if an injury were to occur as a result of the sponsor's negligence.

Part I of the article reviews liability waivers in extreme sports and the laws in various states regarding liability waivers. Part II explores the doctrine of assumption of risk. This section will review primary and secondary assumption of risk. Additionally, this section will also discuss the inherent risks involved in extreme sports and the duty owed by the sponsor to the athlete. Part III calls for possible solutions to the problem of liability waivers allowing sponsors to be exempt from their own acts of negligence. This section will propose that legislative action should be taken to enact statutes that address the inherent risks involved in each extreme sport. Another solution involves recommending that courts, when determining whether a liability waiver is valid against an athlete after the athlete has sustained an injury, conduct an assumption of risk analysis. The article concludes with a proposal to change the language used in extreme sports liability waivers.

\section{Liability Waivers in Extreme Sports}

Extreme sports have a high risk of injury, possibly even death. Athletes, however, still pursue these types of sports. In order for the athlete to pursue this sport, someone must sponsor and organize the event. In putting on the event, the sponsor will want to make sure that in the unfortunate event that an athlete sustains an injury, the sponsor will be insulated from any and all liability. Therefore, the sponsor will likely create a liability waiver that the athlete will sign before competing in the event. In many of these waivers, also known as express assumption of risk, the defendant owes no duty to protect the plaintiff from a known risk because the plaintiff, in advance, has given his express consent to relieve the defendant of an obligation of conduct toward him. ${ }^{25}$ The result is that the defendant is relieved of any legal duty to the plaintiff; and being under no duty, the defendant cannot be charged with negligence. ${ }^{26}$

\section{A. An Example of a Liability Waiver}

The contract below, from the International Free Skiers Association [Hereinafter, "IFSA"], shows the exact language that a sponsor has used to exempt him or herself from all liability:

25. Knight v. Jewett, 834 P.2d 696, 703 (Cal. 1992).

26. $I d$. 


\title{
INTERNATIONAL FREE SKIERS ASSOCIATION EVENTS
}

\author{
PLEASE READ CAREFULLY BEFORE PRESSING \\ THE AGREE BUTTON.

\section{THIS IS A RELEASE OF LIABILITY AND WAIVER OF CERTAIN LEGAL RIGHTS.}

1. Being at least 18 years old or has signed release by Parent or guardian for ages 12-17 (hereinafter referred to collectively as "Competitor").

2. Competitor warrants and represents that he/she is in good health and there are no special problems associated with the care of the Competitor and the undersigned parent or guardian (if applicable) has left no special instructions regarding the Competitor.

3. Competitor accepts and understands that alpine skiing in its various forms is a HAZARDOUS sport that has many dangers and risks. It is further understood that training or racing competitively is more HAZARDOUS than recreational skiing. Competitor realizes that injuries are common and ordinary occurrence of this sport. Competitor agrees as a condition of being allowed to compete in an IFSA sanctioned event and use the ski area facility and premises, that Competitor freely accepts and voluntarily ASSUMES ALL RISKS OF PERSONAL INJURY OR DEATH or for property damage which results in any way from negligence, conditions on or about the premises and facilities, the operation of the event including, but not limited to, grooming, snow making, ski lift operations, actions or omissions of employees or Board of Directors of the International Free Skiers Association or Competitor's participation in skiing, training, any competitive event, or other activities at the event.

Competitor agrees with the premise that Competitor is a competitor at all times, whether practicing for competition or in competition. Competitor agrees that he/she is always provided an opportunity to conduct a reasonable visual inspection of the training race course. Competitor understands that he/she will be held to assume the risk of all course conditions, course construction, or layout and obstacles.

\section{W A R N I N G}

A skier assumes the risk of any injury to person or property resulting from any of the inherent dangers and risks of skiing and may not recover from any International Free Skiers Association employee or Director for any injury resulting from any of the inherent dangers and risks of skiing including: Changing weather conditions; existing and changing snow conditions; bare spots; rocks; stumps; trees; collisions 
with natural objects, man-made objects, or other skiers; variations in terrain; and the failure of skiers to ski within their own abilities.

4. Competitors hereby assumes all risks which may be associated with and/or result from his/her involvement in such Activity and releases and indemnifies International Free Skiers Association (IFSA), its subsidiaries and affiliates, their respective officers, directors, agents, servants, and employees (hereinafter International Free Skiers Association (IFSA)), of and from any liability, claims, demands, actions and causes of action whatsoever arising out of or related to any loss, damage or injury, including death, that may be sustained by me while participating in the Activity, including, but not limited to, those injuries and damages caused by the negligence and or breach of warranty, express or implied, on the part of International Free Skiers Association (IFSA).

5. By execution of this release International Free Skiers Association (IFSA) shall be indemnified for any injury to other person(s) or property which Competitor may cause as a result of engaging in the Activity.

6. Competitor authorizes International Free Skiers Association (IFSA) and/or its authorized personnel to call for medical care for him/her or to transport him/her to a medical facility or hospital if, in the opinion of such personnel, medical attention is needed for him/ her. Competitor agrees that upon his/her transport to any such medical facility or hospital that International Free Skiers Association (IFSA) shall not have any further responsibility for him/her. Further, Competitor agrees to pay all costs associated with such medical care and related transportation provided for him/her and shall indemnify and hold harmless International Free Skiers Association (IFSA) of and from any costs incurred therein.

7. COMPETITOR CONTRACTUALLY AGREES that any and ALL DISPUTES between himself/herself and International Free Skiers Association (IFSA) arising from his/her use of equipment and/or participation in the Activity OR use of this equipment, and INCLUDING and claims for personal injury and/or death, WILL BE GOVERNED BY THE LAWS OF THE STATE OF CALIFORNIA and EXCLUSIVE JURISDICTION thereof will be in the state of court residing in the county where the alleged tort occurred or the federal courts of the state of California.

8. IN THE EVENT ANY SECTION OF THIS RELEASE IS FOUND TO BE UNENFORCEABLE, THE REMAINING TERMS SHALL BE FULLY ENFORCEABLE. . 
9. This release shall be binding upon Competitor's assignees, subrogors, distributees, heirs, next of kin, executors, personal representatives, and administrators and may be pled by International Free Skiers Association (IFSA) as a complete bar and defense against any claim, demand, action or causes of action by or on behalf of the Competitor.

I HAVE CAREFULLY READ THE FORGOING LIABILITY RELEASE, UNDERSTAND ITS CONTENTS AND CLICK AGREE WITH FULL KNOWLEDGE OF ITS SIGNIFICANCE. ${ }^{27}$

The contract above poses several problems for the competitors. Most notably, the IFSA will not be responsible for any acts of their own negligence. The IFSA stated that they would not be responsible for any property damage or injury to the athlete, even if it resulted from their own negligence. ${ }^{28}$ An athlete that signs this is agreeing that if he or she receives an injury as a result of IFSA's negligence, IFSA will not be liable for any damages. As a result of this, an athlete could be left with thousands of dollars in medical bills and extreme pain and suffering. An athlete may still try to bring claims against associations such as IFSA, asserting that the liability waiver should not be valid. Courts, however, have been split on whether liability waivers should be valid or void as against public policy.

\section{B. A View of Liability Waivers from Various State Courts}

\section{Banfield v. Louis ${ }^{29}$}

Susan Banfield, before competing in a triathlon in Ft. Lauderdale, Florida, signed a "release" or "waiver" relieving the race sponsors, organizers, and promoters of any and all liability. ${ }^{30}$ While Banfield was riding her bicycle on the designated bicycle race course on the day of the event, she was struck and seriously injured by a motor vehicle operated by Louis. ${ }^{31}$ Banfield subsequently filed suit against the event sponsors, alleging that they breached their duty to Banfield by failing to maintain a safe bicycle course. ${ }^{32}$ The court began its analysis by stating that in Florida, waiver clauses are not looked upon with favor, but will be valid and enforceable if the intent to relieve a party of its own negligence is clear and unequivocal. ${ }^{33}$ The court reasoned

27. E-mail from Chris Tatsuno, Member, Int. Free Skiers Assoc., copy of IFSA Release of Liability and Waiver (Sept. 26, 2011, 09:02 EST) (on file with author).

28. Id.

29. Banfield v. Louis, 589 So. 2d 441 (Fla. . Dist. Ct. App. 1991).

30. Id. at 443 .

31. Id.

32. Id.

33. Id at 444. 
that when Banfield signed the waiver, she knew that she was releasing all of the sponsors and promoters, as well as their agents, from liability. ${ }^{34}$ Additionally, the court held that although Banfield expressed legitimate public safety concerns, "it was a matter of great public concern that freedom of contract not be interfered with." 35

\section{Dare v. Freefall Adventures, Inc. ${ }^{36}$}

Joseph Dare was injured in a sky diving accident when he attempted to avoid colliding with Eric Johnson, a co-participant in the jump. ${ }^{37}$ Prior to jumping, Dare released Freefall Adventures from any claims of injuries arising from Freefall's negligence. ${ }^{38}$ In New Jersey, disclaimers or limitations of liability are generally not favored. ${ }^{39}$ The court, before its analysis, discussed how they had never addressed release/waiver agreements in the context of skydiving, but had done so in the context of skiing. ${ }^{40}$ In the context of skiing, a release from liability for injuries arising from the activity may be void as public policy because of its adhesive nature, and, furthermore, because the release cannot relieve the owner of the ski resort from its statutory duty of care. ${ }^{41}$ The court in this case ruled that the operator did not breach its duty of care in how the facility was run, nor did the operator materially increase the risk of injury to the skydiver beyond those reasonably anticipated by skydiving participants. ${ }^{42}$ The operator, therefore, was not liable. ${ }^{43}$

\section{Klem v. Chaplinsky $y^{44}$}

Thomas Klem was injured after participating in a deck hockey game at the Sports Arena. ${ }^{45}$ The Sports Arena argued that Klem was barred from bringing a negligence claim against them, because he had signed a liability waiver. ${ }^{46}$ In Connecticut, courts do not favor con-

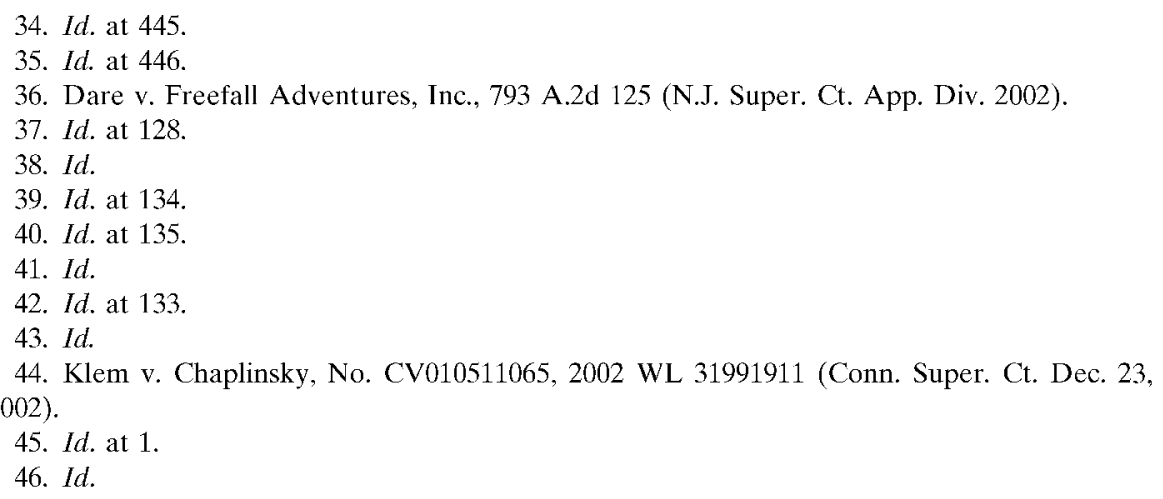


tract provisions that relieve a person from his own negligence. ${ }^{47}$ Such provisions have been upheld, however, when both parties have assented to the terms of the waiver. ${ }^{48}$ The majority of trial courts in Connecticut also take the position that specific language, i.e., the word "negligence" must be present in negligence waivers to effectively waive claims for negligence against facility operators. ${ }^{49}$ In Klem, the court found the waiver not to be valid because the waiver did not contain the appropriate language to sufficiently absolve the Sports Arena of liability for its own negligence. ${ }^{50}$

\section{Gregorie v. Alpine Meadows Ski Corp. ${ }^{51}$}

Jessica Gregorie was snowboarding in California.52 While on the mountain, Gregorie began to hike a traverse. ${ }^{53}$ While hiking, she slipped due to the icy condition of the snow and slid over a rock. ${ }^{54}$ Gregorie subsequently died. ${ }^{55}$ In California, liability waivers will be found to be sufficient as long as the release constitutes a clear and unequivocal waiver with specific reference to a defendant's negligence. ${ }^{56}$ The scope of the waiver must also be clear. ${ }^{57}$ An act of negligence is reasonably related to the object or purpose for which the release was given if it is included within the express scope of the release. ${ }^{58}$ In the current case, the release stated that Gregorie agreed to release Alpine Meadows from liability for any damages, injury, or death arising from her participation in the sport of skiing, including the alleged negligence of Alpine Meadows. ${ }^{59}$ The court found that the release was clear and unambiguous, and it served as sufficient notification to Gregorie was he was giving up any future claim against Alpine Meadows for negligence. ${ }^{60}$ Therefore, the court found the release to be a valid and enforceable waiver of liability. ${ }^{61}$

\footnotetext{
47. Id. at 6 .

48. $I$ d.

49. Id. at 7 .

50. Id. at 11 .

51. Gregorie v. Alpine Meadows Ski Corp., 2009 U.S. Dist. LEXIS 69237 (E.D. Cal. 2009).

52. Id. at 4 .

53. Id.

54. $I d$.

55. $I d$.

56. $I d$. at 52 .

57. Id. at 55 .

58. $I d$. at 56.

59. Id. at 57.

60. Id.

61. Id. at 59.
} 


\section{Waivers of Liability in High Risk Sports}

The cases above discussed various state courts and their laws regarding liability waivers. However, international courts also have their own laws with regards to waivers and releases of liability. Specifically, Ontario, Canada has implemented a three staged analysis to determine whether a waiver of liability is valid and enforceable in high risk sports. The analysis is as follows:

Is the release valid in the sense that the plaintiff knew what he or she was signing?

What is the scope of the release and is it worded broadly enough to cover the conduct of the defendant?

Should the release not be enforced because it is unconscionable? ${ }^{62}$

The first part of the analysis focuses on whether the plaintiff signed the release with the knowledge that it was a legal document affecting his or her rights. ${ }^{63}$ If the defendant can establish this element, the release will be valid, regardless of whether the plaintiff read and understood the document prior to its execution. ${ }^{64}$ The second part of the analysis requires the court to interpret the clause as to whether or not it operates to exonerate the defendant from liability. ${ }^{65}$ The release should explain the particular types of negligence that it intends to exclude. ${ }^{66}$ If the court finds the release to be broad enough to exonerate the defendant from all liability, including negligence, then it will likely find the clause to be valid as well. ${ }^{67}$ The third part of the analysis focuses on whether the release should not be enforced because it is unconscionable. ${ }^{68}$ A release will be found unconscionable, and therefore unenforceable, where it sufficiently diverges from community standards of fairness and morality. ${ }^{69}$ A release will not diverge from community standards of fairness and morality where it can be shown that the plaintiff knew of the inherent risks associated with the sport. ${ }^{70}$

After looking at cases from the United States and Canada, it can be concluded that courts do not look upon liability waivers favorably, but

62. Peter Cronyn \& Jessica Fullerton, Waivers of Liability in High Risk Sports: A Review of Isildar v. Kanata Diving Supply, 28th Annual Civil Litigation Conference (Nov. 28, 2008), p. 3, available at http:/www.nelligan.ca/publications/e/Waivers_of_Liability_in_High_Risk_Sports1. pdf

63. $I d$. at 4 .

64. Id. at 5 .

65. Id. at 9 .

66. Id. at 14 .

67. Id. at 10 .

68. Id. at 3 .

69. Id. at 11 .

70. Id. at 12 . 
will be found to be valid if particular criterion are fulfilled. Both Canadian and United States court systems have held that the scope of the waiver must be broad enough to include each defendant and each defendant's potential liability, including the act of negligence. ${ }^{71}$ The plaintiff must also know what he or she is signing and must assent to the terms of the waiver. ${ }^{72}$ If these factors are met, a court will likely the waiver to be valid and an athlete may not be able to bring an action for negligence against the sponsor. However, a finding of validity of a waiver should not end the court's analysis. Recovery for an injured individual should not be barred, simply because the individual is aware that an activity involves a risk of harm that may arise from another's negligence and then voluntarily proceeds to participate in that activity. Participating in a potentially dangerous sport does not mean that an athlete consents to a breach of duty by others that increases the risks posed by the sport itself.Therefore, it is important to determine the inherent risks of the sport and whether the sponsor owes a duty to the participants under the doctrine of assumption of risk.

\section{The Doctrine of Assumption of Risk}

The traditional doctrine of assumption of risk involves a plaintiff who voluntarily assumes a risk of harm arising from the negligent or reckless conduct of the defendant. ${ }^{73}$ The plaintiff subsequently cannot recover for such harm arising from the defendant's conduct. ${ }^{74}$ Therefore, assumption of risk operates as a complete defense against all liability, negligent conduct as well as reckless conduct. ${ }^{75}$ The traditional doctrine of assumption of risk became problematic, however, when most jurisdictions recognized that it was no longer defensible to completely bar recovery to a plaintiff who voluntarily assumed a risk of harm. ${ }^{76}$ Assumption of risk is now divided into two separate forms: primary assumption of risk and secondary assumption of risk.

\section{A. Primary Assumption of Risk}

Within the doctrine of primary assumption of risk, the defendant owes no duty to protect the plaintiff from a particular risk of harm. ${ }^{77}$

71. See id. at 14; see also Gregorie, supra note 51, at 56; see also Klem, supra note 44, at 7.

72. See Cronyn, supra note 62 , at 4; see also Klem, supra note 44, at 6.

73. Restatement (SECOND) OF ToRTs $\$ 496$ A (1965).

74. $I d$.

75. $I d$.

76. See Hornton, supra note 13 , at 611.

77. Knight v. Jewett, 834 P.2d 697, 704 (Cal. 1992). 
However, defendants do owe a duty to not increase those risks inherent in the sport. ${ }^{78}$ If there is no duty of care owed (i.e. the defendant does not increase those risks inherent in the sport), the plaintiff's assumption of the risk acts as a complete bar to the plaintiff's cause of action. ${ }^{79}$ The doctrine bars liability because the plaintiff is said to have assumed the particular risks inherent in a sport by choosing to participate in said sport. ${ }^{80}$ Thus, a court must evaluate the fundamental nature of the sport and the defendant's role in or relationship to that sport in order to determine whether the defendant owes a duty to protect a plaintiff from a particular risk of harm. ${ }^{81}$ A duty analysis under primary assumption of risk also turns on the question of whether a given injury is within the "inherent" risk of the sport, which can only be determined by looking at a particular sport and how it is played. ${ }^{82}$

An activity falls within primary assumption of risk if the activity is done for enjoyment or thrill, requires physical exertion as well as elements of skill, and involves a challenge containing a physical risk of injury. ${ }^{83}$ For example, Morgan v. New York is a case where primary assumption of risk barred the plaintiff's claim against the defendant for injuries that the plaintiff sustained. ${ }^{84}$ In Morgan, Sean Morgan was injured during a competition while driving a two-person bobsled. ${ }^{85}$ Morgan commenced a negligence action against the State of New York, alleging defective design of the bobsled run. ${ }^{86}$ The court stated that it was the duty of the State "to make the [bobsled run] as [it] appeared to be and if the risks of the activity were fully comprehended or perfectly obvious, plaintiff [must be found to have] consent to them and defendant [to have] performed its duty" .87 The court held that Morgan fully comprehended the risks presented by the dangerous nature of bobsledding, which included the way that the bobsled run was constructed. Therefore, the court found no breach of duty by the State of New York. ${ }^{88}$

\footnotetext{
78. Id. at 709 .

79. O'Donoghue v. Bear Mountain Ski Resort, 30 Cal. App. 4th 188, 192 (Cal. Ct. App. 1994).

80. Truong v. Nguyen, 156 Cal. App. 4th 865, 876-77 (Cal. Ct. App. 2007).

81. Id.

82. Staten v. Super. Ct. of Alameda Cnty., 45 Cal. App. 4th 1628, 1635 (Cal. Ct. App. 1996).

83. Calhoon v. Lewis, 81 Cal. App. 4th 108, 115 (Cal. Ct. App. 2000).

84. Morgan v. . New York, 645 N.Y.S.2d 614 (N.Y. App. Div. 1996).

85. Id.

86. Id. at 616, (quoting Giordano v. Shanty Hallowed Corp., 209 A.D.2d 760, 760 (N.Y. App. Div.3d Dept.).

87. Id. at 617.

88. $I d$.
} 


\section{Inherent Risks involved in a Sport}

In the sports setting, conditions or conduct that otherwise might be viewed as dangerous often are an integral part of the sport itself. ${ }^{89}$ In the sport of freestyle skiing, moguls pose a risk of harm to skiers that might not exist were the moguls removed. ${ }^{90}$ However, the challenge and risks posed by the moguls are part of the sport of skiing, and a sponsor of an event has no duty to eliminate them. ${ }^{91}$ When doing an analysis under primary assumption of risk, it is important to look at the inherent risks involved in a particular sport. Not only do sponsors of the activity have a duty to sports participants to not increase the inherent risks of a sport, but the sports participants should also be aware of what those inherent risks are so that they are adequately informed as to what types of injuries a sponsor should not be liable for. 92

To determine a sport's inherent risks, a judge should consider if eliminating the risk would (1) chill vigorous participation in the sport and (2) alter the fundamental nature of the activity. ${ }^{93}$ For example, if operators of ski resorts were required to eliminate the danger of falling in difficult terrain, the prospect of liability would effectively terminate the business of a ski resort operation. ${ }^{94}$ California courts have also held that in regards to skiing and snowboarding, there are certain inherent risks that the sponsor of an event has no duty to eliminate or mitigate. ${ }^{95}$ These risks include: moguls on a ski run, trees bordering a ski run, snow-covered stumps, variations in terrain, changes in surface or subsurface snow conditions, bare spots, other skiers, and snowmaking equipment. ${ }^{96}$ Whether a skier personally saw the hazard is irrelevant to the issue of whether the risk is one inherent in the sport of skiing. ${ }^{97}$

\footnotetext{
89. Knight v. Jewett, 834 P.2d 697, 708 (Cal. 1992).

90. Id.

91. Id.

92. Gregorie v. Alpine Meadows Ski Corp., 2009 U.S. Dist. LEXIS 69237, at 23 (E.D. Cal. 2009).

93. Sanchez v. Hillerich \& Bradsby Co., 104 Cal. App. 4th 703, 712 (Cal. Ct. App. 2002).

94. Gregorie, 2009 U.S. Dist. LEXIS at 29.

95. Id. at 24-25.

96. O'Donoghue v. Bear Mountain Ski Resort, 30 Cal. App. 4th 188, 193 (Cal. Ct. App. 1994).

97. Id.
} 


\section{B. Inherent Risk Statutes}

Sport safety statutes exist in most states to protect sport and recreation providers from liability. ${ }^{98}$ These statutes place responsibility on participants for voluntarily assuming the inherent risks in a particular sport. ${ }^{99}$ The most common types of sport safety statutes provide legislative protection for activities such as snow skiing, snowboarding, roller skating, equestrian activities, hang gliding, snowmobiling, and whitewater boating. ${ }^{100}$ Defining inherent risks has become a key aspect of many sport specific legislative initiatives. ${ }^{101}$ However, few inherent risk statutes address extreme sports. ${ }^{102}$

The justification for providing legislative protection for sport activities is primarily economic. ${ }^{103}$ Sport safety statutes are designed with a focus on maintaining a balance between economics and athlete safety. ${ }^{104}$ For example, skiing is a popular activity in many states that have the right combination of terrain and weather conditions for skiing. ${ }^{105}$ Ski resorts draw visitors from many different states, which often has a positive economic impact on the regional and state economies. ${ }^{106}$ Therefore, the purpose of legislative initiatives is to decrease the costs associated with litigation and to keep ski operators in business. ${ }^{107}$

States vary as to what inherent risks an athlete assumes when participating in a specific sport. ${ }^{108}$ For example, twenty-six states have statutory provisions that address the inherent risks that participants assume when skiing. ${ }^{109}$ For the states that have statutes that fail to list the inherent risks, the statutes are open for interpretation of what constitutes an inherent risk. ${ }^{110}$ Vermont, for example, states that inherent risks are those which are "obvious and necessary."111 Fortyone states have statutory provisions that address the inherent risks

98. John O. Spengler \& Brian P. Burket, Sport Safety Statutes and Inherent Risk: A Comparison Study of Sport Specific Legislation, 11 J. Legal Aspects of Sport 135 (2001).

99. Id.

100. Id

101. Id.

102. See Hornton, supra note 13 , at 619.

103. Spengler, supra note 98 , at 135.

104. Id.

105. Id

106. $I d$.

107. Id.

108. $I d$.

109. Id. The states that list inherent risks are: Alaska, Colorado, Connecticut, Idaho, Maine, Massachusetts, Michigan, New Hampshire, New Jersey, New Mexico, North Dakota, Ohio, Oregon, Tennessee, and Utah.

110. Spengler, supra note 98, at 135.

111. Id. 
participants assume when riding horses, and eleven states have statutory provisions that address the inherent risks participants assume when roller-skating. ${ }^{112}$ There is little uniformity, however, in the states that have statutes addressing the inherent risks associated with skiing, roller-skating, and equestrian activities. ${ }^{113}$

The following case of Collins v. Schweitzer, Inc. showcases the effect of an Idaho sport safety statute regarding the inherent risks involved in the sport of skiing. ${ }^{114}$ In Collins, Michael Collins was competing in a ski race on Schweitzer Mountain, which located in Northern Idaho. ${ }^{115}$ During the race, Collins was skiing alongside another racer. ${ }^{116}$ In an attempt to avoid the other racer after they had passed the finish line, Collins lost control, slid through some netting, and collided further down the hill with a lift tower that was in the vicinity of the racecourse. ${ }^{117}$ The lift tower was padded, but the padding did not prevent Collins from breaking his neck in the collision. ${ }^{118}$ Collins claimed that the resort and ski race sponsor were negligent when they designed the racecourse so close to the lift tower. ${ }^{119}$ The Idaho statute, lists injuries caused by lift towers as an inherent risk that is assumed by the skiers. ${ }^{120}$ Given the language of the statute, paired with a finding that the risk of colliding with the lift tower was not increased by Schweitzer's placement of the racecourse, the court held in favor of Schweitzer Ski Resort.121

Although the Collins case demonstrates how a sport safety statute can bar relief to an injured athlete, there may be circumstances where a sport safety statute can allow recovery. For example, as a snowboarder is snowboarding down a run, he sees a mound of snow on the side of the run that looks like a jump. The snowboarder goes over to the mound of snow and jumps off of it, subsequently suffering an injury. The snowboarder brings an action against the ski resort for negligently maintaining the mountain by not removing the mound of snow. The state that this incident took place in has a sport safety statute, but the statute states that the inherent risks involved with snowboarding are those that are obvious and necessary. A court may

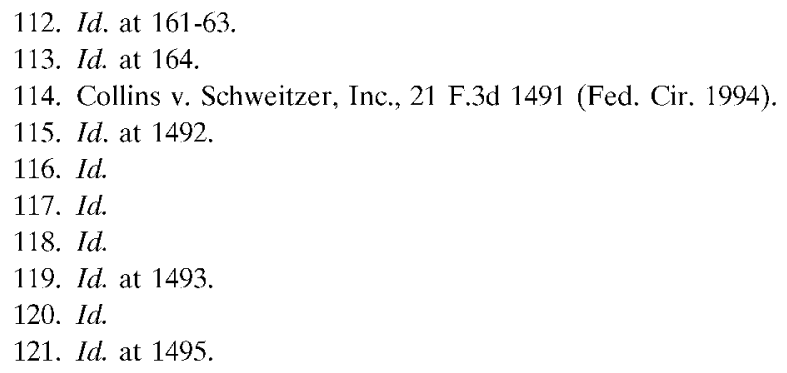


decide that a mound of snow on the side of a run is a risk that is not obvious and necessary in the sport of snowboarding. If the statute was specific as to what the inherent risks were, there would be no question as to whether a mound of snow on a ski run is considered an inherent risk. Therefore, defining what the inherent risks are in a particular sport is vital to a court's analysis of primary assumption of risk as well as secondary assumption of risk.

\section{B. Secondary Assumption of Risk}

Secondary assumption of risk applies when the risk that causes the plaintiff's injuries was caused by actions of the defendant which increased an inherent risk of the sport. ${ }^{122}$ The defendant has breached the duty of care owed to the plaintiff through the increasing of an inherent risk. ${ }^{123}$ The breach of duty occurs when the defendant increases the risk of injury beyond that inherent in the sport, not when the defendant's conduct may have increased the severity of the injury suffered. ${ }^{124}$ Imposing liability on these defendants for increasing the risks of a sport is justified because they are in control of the conditions under which the plaintiff engages in the sport. ${ }^{125}$ However, this policy justification does not extend to a defendant who is wholly uninvolved with and unconnected to the sport. ${ }^{126}$

Under secondary assumption of risk, the defendant is not entitled to be relieved of liability for an injury proximately caused by such breach of duty. ${ }^{127}$ The plaintiff will also share the fault for his or her injury. ${ }^{128}$ Even though the plaintiff will share the fault, the plaintiff's voluntary decision to face the risk inherent in a sport does not operate as a complete bar to recovery, but rather functions as a form of comparative fault. ${ }^{129}$ Under comparative fault, the responsibility of both parties is relevant because an injury has been caused by both a defendant's breach of a legal duty to the plaintiff and the plaintiff's voluntary decision to engage in an unusually risky sport. ${ }^{130}$ Application of comparative fault will not relieve either individual of responsibility for his or her actions but rather will ensure that neither party will escape

122. O'Donoghue v. Bear Mountain Ski Resort, 30 Cal. App. 4th 188, 192 (Cal. Ct. App. 1994).

123. Knight v. Jewett, 834 P.2d 697, 704 (Cal. 1992).

124. Calhoon v. Lewis, 81 Cal. App. 4th 108, 116 (Cal. Ct. App. 2000).

125. Id. at 117 .

126. $I d$

127. Knight, 834 P.2d at 704.

128. Rosencrans v. Dover Images, Ltd., 192 Cal. App. 4th 1072, 1083 (Cal. Ct. App. 2011 ).

129. Truong v. Nguyen, 156 Cal. App. 4th 865, 878 (Cal. Ct. App. 2007).

130. Knight, 834 P.2d at 707-08. 
such responsibility. ${ }^{131}$ Therefore, damages under secondary assumption of risk will be apportioned between the parties. ${ }^{132}$

An example of a case that portrays secondary assumption of risk is Rosencrans v. Dover Images, Ltd. Under Rosencrans, Jerid Rosencrans, while practicing before a motocross competition, went up a ramp for a jump and fell on the downslope of the ramp, which placed him outside the view of the other riders. ${ }^{133}$ Fifty seconds later, two motorcyclists struck Rosencrans, causing him to sustain serious injuries. ${ }^{134}$ There was at least one caution flagger at the track when Rosencrans fell. However, at the time of the fall, the caution flagger was not on the platform near the location where Rosencrans fell. ${ }^{135}$ The court stated that even though jumps and falls are inherent risks in motocross competitions, an owner and operator of a track has a duty not to increase those inherent risks and to provide a warning system, such as caution flaggers, to alert other riders of a fallen participant on the track. ${ }^{136}$ Therefore, because a caution flagger was not near the location where Rosencrans fell, Dover Images breached the duty it owed to Rosencrans. ${ }^{137}$

\section{Duty}

It has been established that defendants generally have no legal duty to eliminate risks inherent in the sport itself, but do have a duty to not increase the risks to a participant over and above those inherent in the sport. ${ }^{138}$ This duty requires an owner or operator to minimize the risks without altering the nature of the sport. ${ }^{139}$ As a matter of public policy, a duty of care should not apply when compliance with the duty would require that an integral part of the sport be abandoned or would discourage vigorous participation in sporting events. ${ }^{140}$ For example, taking moguls out of the sport of skiing or jumps out of the sport of motocross would probably discourage participation in those sports. In the sport of motocross, jumps and falls are inherent to the sport. ${ }^{141}$ Therefore, there is no duty to eliminate the jumps entirely,

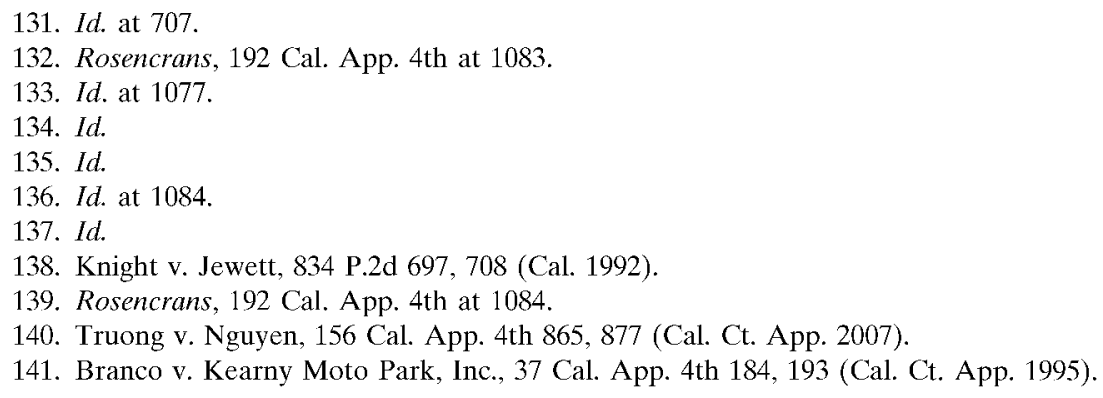


and there is no duty to protect against injuries that arise from reasonably designed jumps. ${ }^{142}$ However, the sport does not require jumps to be designed in such a way as to create an extreme risk of injury. ${ }^{143}$

A case that exemplifies the principle above is Branco v. Kearny Moto Park, Inc. In Branco, Brandon Branco was racing his bicycle on Kearny Moto Parks [Hereinafter, "KMP"] BMX course when his bicycle crashed and struck the side wall of an expert caliber jump's landing area. ${ }^{144}$ Branco suffered a broken neck, which resulted in permanent quadriplegia. ${ }^{145}$ As a result, Branco brought an action, alleging that KMP's expert caliber jump was negligently designed because the design increased the inherent risks involved in the sport of BMX. ${ }^{146}$ The court stated that commercial operators of sports facilities owe a duty to their patrons to ensure that the facilities and related services do not increase the risk of injury above the level inherent in the sport. ${ }^{147}$ Branco provided an expert witness that testified that the first hill of the jump was too steep, and such design puts the rider at an extreme risk because the rider is subsequently in an extremely unbalanced position. ${ }^{148}$ The expert also testified that the distance between the two hills of the jump is so great that the rider has to be moving at a very high rate of speed to make the second jump. ${ }^{149}$ Finally, the expert concluded that both of these factors tend to put riders at a risk because they put the rider at the very end of their ability. ${ }^{150}$ The court was persuaded and held that there was a triable issue of fact regarding whether KMP's jump was negligently designed. ${ }^{151}$

Even though there is a duty owed to a bicycle racer injured on a bicycle jump which by its design creates an extreme risk of injury, there is no duty owed to a skier injured on a mogul. ${ }^{152}$ There is a distinction between the degrees of control exercised over the creation of nature-made obstacles involved in the sport of skiing and manmade obstacles in the sport of motocross. ${ }^{153}$ However, even if there is no duty owed to skiers who ski over a mogul, there could be a duty owed to skiers who perform tricks over a jump that is man-made. For

\footnotetext{
142. $I d$.

143. $I d$.

144. Id. at 187.

145. Id

146. Id. at 186 .

147. Id. at 191 .

148. Id. at 188 .

149. Id. at $188-89$.

150. Id. at 189 .

151. Id at 186 .

152. Id. at 193.

153. $I d$.
} 
example, if the sponsors of a skiing/snowboarding event construct jumps within the racecourse and make those jumps mandatory (if the athlete misses the jump, the athlete would become disqualified), a duty could be imposed if the jumps were designed in a way that creates an extreme risk of injury above and beyond what was already considered an inherent risk in the sport. A skier/snowboarder already assumes the inherent risk that man-made jumps create (the possibility of falling and sustaining an injury), but a skier/snowboarder should not have to assume the risk that the jump was designed in a way that makes the likelihood of an injury more severe. Therefore, a sponsor of a sporting event will have a duty to provide a reasonably safe course or track. ${ }^{154}$

Applying a duty standard to extreme sports is practical if an athlete wishes to recover for injuries that he or she sustained. If duty was not an issue, sponsors could provide an activity and avoid liability for injuries that could be foreseeable as a result of their negligence. Courts, however, have struggled to apply the duty not to negligently increase the inherent risks involved in extreme sports because it is arguably difficult to define what constitutes "negligence" when injuries in such sports are a common occurrence. ${ }^{155}$ It has also been argued that negligence liability for sports related injuries would curtail both participation and the vigorous and active play that is essential to some sporting events. ${ }^{156}$ For example, a California court has found that " $\left.t\right]$ he overriding consideration in the application of primary assumption of risk is to avoid imposing a duty which might chill vigorous participation in the implicated activity and thereby alter its fundamental nature." 157 In Regents of University of California $v$ Superior Court, Norman Roettgen fell and subsequently died during a rock climbing class. ${ }^{158}$ The complaint alleged that the fall was the result of the Regents' negligence in placing four rope anchors into a single crack system. ${ }^{159}$ The court, however, noted that "falling, whether because of one's own slip, a co-climber's stumble, or an anchor system giving way, is the very risk inherent in the sport of mountain climbing and cannot be completely eliminated without destroying the sport itself." 160 Without considering whether the Regents had increased the sport's inherent risks by misplacing the rope anchors, the court held that the risk of

154. Rosencrans v. Dover Images, Ltd., 192 Cal. App. 4th 1072, 1084 (Cal. Ct. App. 2011).

155. See Hornton, supra note 13 , at 656 .

156. Cahill v. Carella, 648 A.2d 169, 172 (Conn. Super. Ct. 1994).

157. Regents of Univ. of Cal. v. Super. Ct., 41 Cal. App. 4th 1040, 1046 (Cal. Ct. App. 1996).

158. $I d$. at 1042 .

159. Id.

160. Id. at 1047 . 
falling from the rock-face is inherent in the sport of rock climbing and can occur at anytime, regardless of the negligence of the Regents. ${ }^{161}$

The case above is an example of why courts need to look at a sport's inherent risks, and whether the defendant negligently increased those risks, before denying liability. If the abovementioned court had considered these factors, it is possible that the family of the student that died as a result of his fall could have recovered for the pain and suffering that they had to endure. Throughout this article, the argument has been that sponsors of an event should be liable for those negligent actions that increase the inherent risks involved in a sport. However, a standard that is fair to both the sponsor of the event and the athlete is also necessary, which is the following section of this Article proposes.

\section{Proposals}

\section{A. Inherent Risk Statutes for Extreme Sports}

There are already sport safety statutes that have been implemented in various states to determine what the inherent risks are in certain sports. ${ }^{162}$ Similar statutes should be created for extreme sports. Each sport that is classified as an extreme sport should have a statute that unambiguously states what the inherent risks are. The statutes should also be implemented in all states where these sports are executed. By having the inherent risks stated in a statute, there should be no confusion for the athletes, the sponsors, and the courts as to what those inherent risks are. The sport specific statutes could then be implemented in the liability waivers that will be used for competitions and events. Before an athlete goes to sign the liability waiver, he or she will be aware of each risk inherent in that specific sport. Thus, the athlete will know exactly what risks he or she is assuming. For example, the aforementioned IFSA contract example in the beginning of this article stated what risks are inherent in the sport of free-skiing. Those risks were listed as: changing weather conditions; existing and changing snow conditions; bare spots; rocks; stumps; trees; collisions with natural objects, man-made objects, or other skiers; variations in terrain; and the failure of skiers to ski within their own abilities. ${ }^{163}$

By the inclusion of clear and comprehensive lists of the inherent risks in the liability waivers, the athlete will have a clear understanding of what the sponsor can and cannot be liable for. This in turn may

161. Id.

162. See supra text accompanying Part II.A.2.

163. See supra text accompanying note 27. 
prevent the sponsor from suffering from future litigation. However, an clear understanding of the inherent risks may also allow the athlete to recgonize when the sponsor does something to increase those risks already inherent in the sport. For example, being injured by manmade objects is a risk that an athlete assumes when participating in free-skiing events. Therefore, an athlete will be aware that by going off a jump, he or she may fall and sustain an injury. However, if the jump is created in a way that increases the likelihood of an injury, and an athlete get injured as a result of the unreasonably created jump, that athlete should be able to bring a claim against the sponsor that is responsible for the creation of that jump. Thus, the existence of inherent risk statutes will help determine when a sponsor owes a duty to an athlete to not increase those risks inherent in a sport.

\section{Opposing Arguments}

Sponsors of an event may be concerned that by implementing inherent risk statutes, an athlete who is injured by a sponsor's negligence will expect to recover his or her entire share of damages. The argument is that once an athlete is fully informed of what the inherent risks are, and then suffers an injury as a result of the sponsor's negligence, the athlete will expect to recover full damages. Sponsors, as a result, may implement precautionary measures that could threaten to remove the "danger" and "thrill" that makes extreme sports so enticing. However, this could be avoided by applying comparative fault to extreme sports. Comparative fault applies when an injury has been caused by both a defendant's breach of a legal duty to the plaintiff and the plaintiff's voluntary decision to engage in an unusually risky sport. ${ }^{164}$ Application of comparative fault principles will not operate to relieve either individual of responsibility for his or her actions, but rather will ensure that neither party will escape such responsibility. ${ }^{165}$ Sponsors, as a result, can still provide the event without having to suffer from having full liability imposed against them because the athlete, by agreeing to participate in such a risky sport, assumes a form of liability as well. Comparative fault can also work to maintain the "thrill" and "danger" that is associated with extreme sports. If the liability is going to be apportioned between the athlete and the sponsor, the sponsor may not feel the need to implement precautionary measures to protect themselves from liability. Comparative fault, therefore, helps to protect both the sponsor from full liability and the

164. Knight v. Jewett, 834 P.2d 697, 708 (Cal. 1992).

165. Id. 
athlete from being denied relief for sustaining an injury that resulted from the sponsor's negligence.

Courts may argue that implementing inherent risk statutes will be difficult because it will be hard to determine what the inherent risks are in sports in which the risk of injury is already high. Courts have held that to determine whether a given injury is within the "inherent" risk of the sport, the determination must be based on a set of factual conceptions of the particular sport and how it is played. ${ }^{166}$ The individuals best situated to explain how the sport is played would be the athletes themselves. After defining how the sport is played, athletes, experts in the field of a particular sport, and sponsors would all be able to provide insight as to what the inherent risks in a sport should be. Therefore, a combined effort of the individuals involved in the sport should be used to determine what the inherent risks are. This combined effort among the athletes, experts, and sponsors should help to reduce disagreements about the inherent risks once an athlete suffers an injury, therefore making it easier to determine whether the sponsor owed a duty to the athlete.

Another argument against implementing inherent risk statutes is that the process will overburden the courts, which are already burdened by the amount of issues that are on their dockets. Implementing inherent risk statutes for every extreme sport will undoubtedly require a lot of time and money. Courts may be reluctant to implement these statutes because of the time that will be required. However, theoretically, if the athletes, the experts within the field, and the sponsors of an event help to create the statutes, there should be less of a burden on the courts. Also, if these statutes are implemented, the courts will not have to spend time on an inherent risk analysis because they can just look to the statute.

Although implementing these statutes may save some time within the court system, their implementation will be costly. However, the majority of states that have already adopted some form of sport safety legislation find that the cost of implementation of the statutes is negated by positive economic impact provided by the sports themselves. ${ }^{167}$ The sport safety statutes also maintain a balance between the economic health of local, state, and regional economies, and the safety of participants. ${ }^{168}$ Therefore, the benefits that will arise from the inherent risk statutes may outweigh the costs associated with them. The statutes, as discussed above, will eventually save the judici-

166. Staten v. Super. Ct. of Alameda Cnty., 45 Cal. App. 4th 1628, 1635 (Cal. Ct. App. 1996).

167. Spengler, supra note 98 , at 165 .

168. Id. 
ary time. Also, by acknowledging what the inherent risks are for each specific sport, the athlete and the sponsor of an event should have a better understanding of what injuries occur as a result of one of those inherent risks or as a result of the sponsor's negligence. This in turn will assist the courts with their analysis of duty under the doctrine of assumption of risk. Therefore, the advantages that inherent risk statutes will create outweigh the incidental burdens associated with imposing the statutes.

\section{B. An Analysis of Assumption of Risk in Extreme Sports}

When courts are deciding whether an individual should be able to recover for an injury that resulted from the defendant's negligence, the analysis should not stop once the validity of the liability waiver has been determined. Courts should also conduct an analysis of assumption of risk in extreme sports cases to determine what the inherent risks are in a particular sport and whether the defendant owed a duty to the plaintiff. Assumption of risk doctrine is even more important in extreme sports cases because the risk of injury is considerably high. An athlete already assumes the heightened risk of sustaining an injury without the threat of the defendant's negligence increasing the likelihood of an injury. If the athlete does suffer an injury as a result of that negligence, the defendant, for public policy reasons, should not be able to escape liability simply because the athlete signed a liability waiver. Therefore, even if the liability waiver is found to be valid, it is fair to the athlete that an assumption of risk analysis be conducted.

Under assumption of risk, a plaintiff may be able to recover if the court finds that the defendant breached the duty he or she owed to the plaintiff by increasing the inherent risks in the sport. ${ }^{169}$ If the defendant breached this duty, comparative fault will work to apportion the damages between the two parties. ${ }^{170}$ If the court finds that the defendant did not owe a duty to the plaintiff, then primary assumption of risk will operate as a complete defense and the plaintiff will not be able to recover for any injuries he or she sustained. ${ }^{171}$ Without an analysis of assumption of risk in every extreme sports case, athletes may have to suffer an injury that was unforeseen, and therefore, was beyond the risk that they voluntarily assumed.

169. See supra text accompanying Part II.B.

170. Id.

171. See supra text accompanying Part II.A. 


\section{Opposing Arguments}

Opponents of applying assumption of risk to extreme sports cite a concern of a potential for increase in litigation and costs. The increase in litigation will arise from athletes realizing that even though they signed a liability waiver, they may be able to recover under assumption of risk. The increased costs will arise from the courts having to conduct an assumption of risk analysis. The question of duty is to be determined by a court, during which the court will have to define the risks inherent in a given sport. ${ }^{172}$ It will take time and money for the courts to define what risks are inherent during participation of a given sport if those risks have not already been defined. Some states have statutes that define the inherent risks in a given sport as those that are obvious and necessary. ${ }^{173}$ However, if such statutes are not in place, it will take time for courts to make the determination to which risks that are obvious and necessary. However, with the proposal that inherent risk statutes be enacted for extreme sports, time and money could be saved. Inherent risk statutes will already have the sport's inherent risks listed, which would, in turn, guide the court in their factual determination regarding the risks. Therefore, conducting an assumption of risk analysis would not be unduly burdensome for the judiciary.

\section{Extreme Sports Liability Waivers Should Be Modified.}

The term "negligence" should be removed from liability waivers. As a matter of public policy, athletes should not have to agree to indemnify a sponsor for his or her negligence that resulted in the an injury to the athlete. Furthermore, with the proposed implementation of inherent risk statutes, the language in liability waivers should be changed. The language as to liability should be changed to include these terms:

The athlete shall understand and assume the inherent risks involved with this sport. The inherent risks for this sport have been provided for through the enactment of the inherent risk statute of this state. By signing this waiver, the athlete agrees that these are risks inherent in this sport. If the athlete subsequently sustains an injury as a result of one of the listed inherent risks, the sponsor of the event will be immune from liability. The athlete, however, does not assume risks above and beyond those already inherent in the sport. Therefore, if the sponsor negligently increases those inherent risks, and the athlete sustains an injury, the athlete will not be barred from brining an action

172. Staten v. Super. Ct. of Alameda Cnty., 45 Cal. App. 4th 1628, 1633 (Cal. Ct. App. 1996).

173. See Spengler, supra note 98. 
against the sponsor. If the athlete does bring an action, the athlete agrees that comparative fault principles will apply to apportion the damages between the athlete and the sponsor.

The terms above modify liability waivers to be fair not only to the athlete but to the sponsor as well.

Modifying liability waivers to be fair to both the athlete and the sponsor will also promote public policy. Generally, preprinted form contracts containing releases from future damages caused by negligence are not favored by the courts and have been held to be against public policy. ${ }^{174}$ However, it could also be argued that imposing all liability on the sponsor as a result of the sponsor's negligence could be against public policy as well because the sponsor may feel the need to implement precautionary measures that have the effect of decreasing the extreme nature of the sport. In order to promote public policy, however, releases from negligence need to be removed from liability waivers. An athlete should not have to suffer an injury as a result of the sponsor's negligence. On the other hand, implementing comparative fault in the language of liability waivers will promote public policy with regards to sponsors because they will still be insulated from certain types of liability. Therefore, modifying liability waivers to be fair to both parties promotes public policy.

Sponsors may argue that not being insulated from all liability will increase litigation against them. However, that is not the case. Even though the athlete does not assume the sponsor's negligence in the revised liability waiver example above, the sponsor will still be immune to some liability. By applying comparative fault, the fault will be apportioned between both parties. The inherent risk statutes can also provide a form of defense for the sponsor in the event that there is a disagreement as to what the inherent risks are. Therefore, modifying liability waivers will protect the athlete from unassuming injuries while continuing to provide protect the sponsor from enduring full liability.

\section{CONCLUSION}

Athletes who participate in extreme sports should not have to endure injuries above those already inherent in the sport. Liability waivers that contract away a sponsor's negligence should be void as against public policy. However, sponsors of an extreme sports event also should not have to endure being liable for every injury that occurs. If

174. Klem v. Chaplinsky, No. CV010511065, 2002 WL 31991911, 7 (Conn. Super. Ct. Dec. 23, 2002). 
that were to happen, sponsors may implement precautionary measures that could destroy the extreme nature of the sport. The extreme nature of the sport is often what makes the sport so appealing to the athlete. Therefore, this article recommends a few proposals that would maintain the extreme nature of the sport, but that would also work to protect the athlete and the sponsor. Implementing inherent risk statutes for each extreme sport is one such proposal that would protect both parties. Applying an assumption of risk analysis to each liability waiver claim is also another proposal. With these proposals, liability waivers should be tailored in a way in which the athletes assume only the risks that are inherent in the respective sport and that do not indemnify sponsors from liability due to the sponsor's negligence. Extreme sports are so different in that danger is inherent in the sport; but athletes, even though they are consenting to the danger by participating in the sport, still need to be protected from injuries resulting from a sponsor's negligence. 